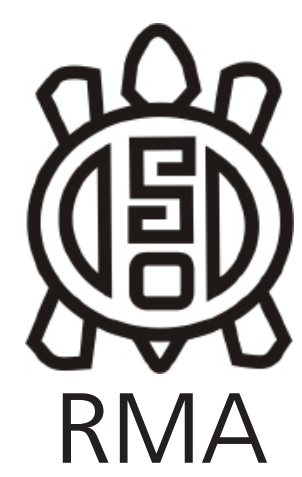

Antropología Social

\title{
Los "últimos caciques" de Cuyo. Tierras, política y memorias indígenas en la Argentina criolla (Mogna, siglos XVII-XIX)
}

\author{
The "last caciques" of Cuyo. Lands, politics and indigenous memories in \\ Creole Argentina (Mogna, XVII-XI centuries)
}

Diego Escolar*

\begin{abstract}
*CONICET. Instituto de Glaciología Nivología y Ciencias Ambientales. Universidad
\end{abstract} Nacional de Cuyo, Argentina. E-mail: descolar@gmail.com

\begin{abstract}
Resumen
Como parte de una "narrativa de extinción" indígena secular, la etnohistoria cuyana dio por sentado la desaparición de los huarpes y por extensión de todos los indígenas en Cuyo en el período colonial, sea por su extinción física como, contradictoriamente, por mestizaje, aculturación o desestructuración social y política. Existen evidencias, por el contrario, de que la experiencia indígena en la región fue mucho más persistente y se articuló en torno a la defensa de territorios y autonomía y el sostenimiento de una memoria colectiva de su aboriginalidad en el proceso colonial. Una de las claves menos exploradas de esta dinámica fue el sostenimiento de un liderazgo indígena incluyendo la reformulación y reforzamiento de algunos cacicatos. Como parte de una reconstrucción de la historia política indígena de la región entre fines del período hispano y la consolidación del estado nacional argentino, en este artículo reconstruiremos las luchas sostenidas por los caciques Alcani de Mogna, en el corazón de San Juan, entre principios del siglo XVIII y comienzos del siglo XIX.
\end{abstract}

Palabras clave: Mogna; Cuyo; Caciques tardo-coloniales; Territorios indígenas; Memorias políticas

\begin{abstract}
As part of a secular "extinction narrative", the historiography took for granted the disappearance of the Indians in Cuyo in the early colonial period, either because of their physical extinction or, contradictorily, due to miscegenation, acculturation or social and political restructuring. There is evidence on the contrary, that the indigenous experience in the region was much more persistent, and articulated around the defense of territories, political autonomy, and the making of a collective memory of their aboriginality and resistance in the colonial process. One of the least explored keys to this dynamic was the indigenous leadership including the reformulation and reinforcement of some chieftains. As part of a reconstruction of the indigenous political history of the Cuyo region, between the end of the Hispanic period and the consolidation of the Argentine national state, I will reconstruct the struggles sustained by the Mogna chiefs, the Alcanis, between the beginning of the 18th century and early 19th century.
\end{abstract}

Keywords: Mogna; Cuyo; Late colonial Caciques; Indigenous territories; Political memories

Los actuales valles centrales de Mendoza y San Juan fueron colonizados desde Chile con la fundación de las ciudades de Mendoza (1561) y San Juan de la frontera (1562). El área, que hasta unas décadas antes estaba incorporada al Tahuantinsuyo incaico, fue denominada Provincia de Guarpes en alusión a los indígenas que mayoritariamente la habitaban, los huarpes. La región perteneció a la capitanía de Chile hasta 1776 cuando pasó a formar parte del virreinato del Río de la Plata. Esto implicó que su historia colonial (y buena parte de la republicana) presente algunas características diferentes de las del resto de la Argentina, tanto por su sometimiento a las decisiones y geopolítica de esa cabecera jurisdiccional como por sus persistentes lazos económicos, políticos y culturales. Pero además de los huarpes, el territorio hacia donde se expandió la jurisdicción al norte, este y sur, estaba poblado también por otros grupos, que en gran parte se mantuvieron libres del dominio colonial. Hacia el sur de Mendoza, en el valle de Uco, los denominados puelches de Cuyo (chiquillanes, morcoyanes, tunuyanes y otros); más al sur, desde el río Diamante, pampas, aucas y pehuenches. Hacia el este, en lo que será la provincia de San Luis, grupos clasificados como comechingones o michilingues entre otros términos. $Y$ en el norte de San Juan, pueblos de habla cacana clasificados como diaguitas, capayanes o yacampis. 
Cuyo presentó durante mucho tiempo una doble frontera de guerra tanto con los grupos denominados genéricamente capayanes o diaguitas, como con los posteriormente incluidos en el "mundo mapuche". Este doble frente se mantuvo hasta la represión del denominado Gran Alzamiento calchaquí de 1632, al cual se plegaron los diaguitas sanjuaninos amenazando tomar la ciudad de San Juan. Las parcialidades puelches y pehuenches del sur de Mendoza, en cambio, vivieron un proceso más paulatino de conquista y hasta fines del siglo XIX se mantendría una frontera con pueblos indígenas libres que se fue trasladando hacia el sur. Los huarpes, primeros en ser incorporados al dominio colonial, fueron reducidos tempranamente. Entre los siglos XVI y XVII, junto con otras parcialidades de la región, sufrieron levas masivas a Santiago y otras áreas del Valle Central y el Norte Chico chilenos (Verdaguer, 1931; Jara, 1958, Prieto, 2001). Estos traslados, que han quedado inscriptos en las memorias de sus descendientes hasta la actualidad, se realizaban a pie y atados a través de los Andes. La intensidad, crueldad y mortandad de estas levas forzosas alimentaron la narrativa de la extinción de los huarpes, que se transformaría más tarde en un postulado sostenido por historiadores y antropólogos (Canals Frau, 1946; Michieli, 1983; Prieto, 1976, entre otros), un ejemplo clásico de temprana desaparición de las etnias indígenas en el continente. La mayor afluencia se produjo entre 1610 y $1670 .{ }^{1}$ Muchos continuaron en sus territorios originales y se trasladaban anualmente por tercios a servir la mita. Las quejas de religiosos de Santiago y vecinos de Mendoza aludieron entonces a un despoblamiento de Cuyo. Junto con la caída en general de las matrículas de encomienda a fines del siglo XVII, y como veremos la tendencia a minimizar la presencia indígena por parte de las elites coloniales, la narrativa de la extinción indígena cuyana quedo grabada y fue retomada por los propios historiadores. Sin embargo, no hay pruebas de la desaparición física de los indios más allá de los posibles cambios en la percepción y clasificación de las identidades, y si información que sugiere su reasentamiento en áreas rurales de Chile y su retorno a Cuyo, como describen numerosos informes ${ }^{2}$ En 1694 luego de varias prohibiciones desoídas, se dictó una Real Provisión que prohibía extraer indios de Cuyo y se ordenaba la restitución de los que habían pasado la cordillera y su reducción en Cuyo "sin embargo de

\footnotetext{
1 En 1613 se consignaron 501 huarpes en Santiago a lo que debe agregarse un número indeterminado en las estancias (Vázquez de Espinosa en Prieto, 2000: 143. Entre 1610 y 1630 el total de encomenderos de indios huarpes ascendió a 34, de los cuales 23 residían en Santiago. Desde 1630 a 1650 hubieron 39 de los cuales 20 estaban situados en Chile y entre 1650 y 1670 de 32 encomiendas 17 pertenecían a feudatarios chilenos (Prieto, 2000:141).

2 El Obispo de Santiago denunciaba en 1626 que los indios "...se vuelven sin licencia de sus encomenderos y otras veces en tiempo de invierno sabiendo que no van a enviar a prenderlos se van a sus tierras huyendo de que ha resultado haberse helado por pasar las cordilleras nevadas." (Testimonio de un Edicto de D. Francisco Salcedo, Obispo de Santiago de Chile, 1936: 277).
}

asiento, concierto o amparo que tengan". ${ }^{3}$ No obstante ello, un número de indios continuó sirviendo en Santiago y Coquimbo a encomenderos chilenos. ${ }^{4}$ Es difícil saber cuántos indígenas retornaron a Cuyo pero el número fue bastante significativo a juzgar por el repentino incremento en las matrículas de encomienda para la fecha, aunque sin que mediaran ya levas masivas, guerras o pestes evidenciando más bien nuevas transformaciones en las clasificaciones, regímenes de trabajo y tributación, en los primeros años del siglo XVIII se redujeron drásticamente los registros hasta casi desparecer a mediados del mismo. ${ }^{5}$

Una de las prácticas intelectuales fundantes de la historia Argentina es la exorcización de los indios del cuerpo de la nación, tanto en el tiempo, proyectándolos al pasado colonial, como en el espacio, representándolos en las fronteras, imaginándolos como un alter radical sin impacto en la sociedad propiamente nacional, blanca y de origen europeo. El caso de la región de Cuyo es paradigmático. ¿Cómo comprender la emergencia de demandas indígenas en el centro-oeste del país, en las lagunas de Guanacache, durante el siglo XIX (y más tarde durante el $X X)$ teniendo en cuenta que la extinción de los indios en el período colonial temprano fue instalada como un axioma histórico y etnológico (Escolar, 2007)?. Los eventos angulares de esta narrativa fueron, primero, las levas masivas que sufrieron los huarpes y otros grupos de la región a los enclaves coloniales chilenos y segundo, el cambio cultural y el intercambio biológico considerados como inevitables vectores de asimilación de los supervivientes por parte de una sociedad colonial persuasiva y compasiva (Michieli, 2000; Prieto 1976, 2001). ${ }^{6}$ Tales nociones, que predominaron hasta hace muy poco, han sido matizadas a veces contradictoriamente por los mismos autores que las aceptaron como postulado científico, cuyas fuentes mostraron la subsistencia de indígenas o sus descendientes en fechas posteriores, pero que igualmente supusieron su pronta desaparición como entidades sociales, políticas y territoriales, debido a la aculturación, el mestizaje o la desestructuración social (Prieto 1975, 2001; Michieli 2000, 2004). Considero que existe sin embargo un tercer elemento basal de la narrativa de extinción indígena cuyana: la falta de una adecuada consideración de la existencia de identificaciones, conflictos, liderazgos y tierras indígenas con posterioridad a la postulada extinción hasta finales del período colonial.

\footnotetext{
${ }^{3}$ Archivo Histórico de Mendoza (AHM), carp. 11, doc. 12.

${ }^{4}$ Archivo Histórico de Mendoza, carp. 29, doc. 12.

${ }^{5}$ En el corregimiento de Mendoza en 1691 estaban matriculados 277 indios, mientras que en 1698, después de la Real Provisión sobre su restitución en Cuyo se registraron 426. En 1715 se registran sólo 45 y en 1719, 12. Ya en 17 (Prieto 2000: 234).

6 Entre 1610 y 1630 el total de encomenderos de indios huarpes ascendía a 34, de los cuales 23 residían en Santiago. Desde 1630 a 1650 hubo 39 de los cuales 20 en Chile; y entre 1650 y 1670, de 32 encomiendas 17 pertenecían a feudatarios chilenos (Prieto, 2001: 141)
} 
La historiografía regional ha mencionado muy tangencialmente que algunas parcialidades defendieron la ocupación de sus tierras hasta el siglo XVIII a través de pleitos judiciales (Morales Guiñazú, 1938) o mediante la "resistencia pasiva" a las fundaciones de Pueblos de Indios de mediados del Siglo XVIII (Méndez y Fanchin 1998; Michieli, 2004). La existencia de derechos de tierras de los indios sin embargo no fue considerada aunque a fines del siglo XVIII era reconocida por autoridades españolas como el marqués de Sobremonte, gobernador intendente de la de la intendencia de Córdoba del Tucumán, jurisdicción de la que pasó a formar Cuyo luego de su separación de Chile y su incorporación en el Virreinato del Río de la Plata. En un informe de 1785 escribió que en San Juan vivían libres, más que en cualquier otra parte de la intendencia "varias familias de mestizos e indios" en especial en Mogna y las Lagunas, donde tenían real provisión de la Audiencia de Chile para el uso de sus tierras, sobre las que no pagaban tributo. Esta Reales Provisiones seguramente eran las dictadas durante la fundación de los pueblos de Mogna, Asunción y San Miguel en 1753 por parte de la Junta de Poblaciones de Chile, que trataremos para el caso de Mogna más adelante.

Las investigaciones que han dado cuenta de la institución cacical en la región durante los siglos XVII y XVIII la han calificado como meramente nominal y políticamente secundaria. Se afirma que, como efectivamente ocurría en diversos contextos hispanoamericanos, eran designados por los corregidores o los propios encomenderos y que no tenían relación con un eventual liderazgo local, siendo su función la administración de los trabajadores para las mitas o la mera presencia formal para el sostenimiento de las encomiendas (Prieto, 2001: 164-167; Michieli, 2000: 14). Según esta perspectiva, hacia fines del siglo XVIIcuando los registros muestran muy escasos padrones de indios tributarios - los caciques y sus familias habrían sido, prácticamente los únicos "indios" que quedaban en unas pocas encomiendas remanentes. ${ }^{7}$ En otras palabras, en Cuyo el cargo de cacique habría sido un mero requisito burocrático del sistema colonial. No es la intención de este trabajo establecer generalizaciones sobre las funciones de los caciques en el período colonial tardío; si me interesa, en cambio, discutir para el caso cuyano la existencia de caciques que sostenían una política indígena de cara a la preservación de las tierras y relativa autonomía de sus poblaciones.

En consonancia con la etnohistoria cuyana, las investigaciones en el área andina tendieron a aceptar un debilitamiento progresivo del poder, convocatoria y representatividad de los caciques o curacas a lo largo del período colonial (por ej. O’Phelan Godoy, 1997). Sin

\footnotetext{
7 Según Catalina Michieli (2000:14-15) esto generaba inclusive que se nombrara como tales a indios comunes, o que caciques difuntos siguieran figurando como titulares e incluso que existieran cacicas hacia finales del siglo XVII, cuando declinaban las matrículas de encomiendas.
}

embargo, esta conclusión fue matizada posteriormente a partir de la constatación de la diversidad regional del rol de las autoridades indígenas, resaltando la importancia del consenso local en su institución y alcance (Serulnikov, 2004). En el norte argentino, en el antiguo Tucumán Colonial, diversidades de menor escala evidencian el carácter variable del poder y rol de los caciques, dependiente de su capacidad política en el entramado de relaciones con los diversos actores de la sociedad colonial (Boixadós, 2008). Analizando el caso del pueblo de Malligasta, en la vecina jurisdicción de La Rioja en el Tucumán, Boixadós (2008) destacó la plasticidad de las estrategias de los caciques, muchas veces ilegítimos, en construir su reconocimiento en base a la alianza con encomenderos, corregidores $u$ otros funcionarios coloniales y las solicitudes de amparo a la Real Audiencia. Lorena Rodríguez por su parte, refiriéndose a los pueblos de Colalao y Tolombón, constó además la relatividad de la división funcional y política entre caciques y autoridades electivas como alcaldes de indios (Rodríguez (2017) y cómo unos y otros podían cumplir similares funciones a la hora de articular la defensa de los derechos comunales. Otro factor mencionado en muchos estudios (ver por ej. Farberman, 2009, para Santiago del Estero), que constataremos para el caso de Mogna, es la creciente integración de agregados, forasteros, soldados no necesariamente considerados indios, sino también mestizos o mulatos, rompiendo con el ideario colonial de la separación de las corporaciones según su origen biológico. No obstante, estos cambios, la misma Farberman (2004) destacó un inusitado proceso de empoderamiento de los caciques en los pueblos de indios de Santiago hacia fines del siglo XVIII hecho que también puede destacarse para Mogna y la vecina Valle Fértil, que analizaré en otro trabajo.

Este cambio de perspectiva se desplegó junto con una creciente ampliación de la mirada sobre la continuidad de los pueblos de indios y las luchas indígenas sobre sus tierras avanzado el siglo XVIII e incluso a lo largo del XIX (López de Albornoz y Bascary, 1998, Boixadós, 1999; López 2006, Fandos y Teruel, 2009; Castro Olañeta y Tell, 2011, Tell, 2012). Este movimiento posiblemente estuvo influido en parte por la creciente visibilización en Argentina de demandas indígenas a partir de la década de 1990 que involucraban memorias y referencias que remitían a un borroso pasado colonial (Isla, 2001; Escolar, 2007). En la medida que Cuyo estuvo integrado a la capitanía de Chile, es importante destacar que a pesar de prejuicios instalados, algunos estudios trasandinos recientes señalan también la persistencia de antiguos pueblos de indios en el Chile central y norte Chico (Contreras Cruces 2007, Godoy Orellana y Contreras Cruces, 2008; Contreras Cruces y Godoy Orellana, 2019; León Solís 2011, 2013; Molina Otárola y Campos Muñoz, 2017). Liderados por caciques o autoridades civiles que representaban también políticamente la continuidad de demandas indígenas, muchas comunidades persistieron 
en sus tierras hasta el siglo XIX y algunas hasta avanzado el siglo XX (Godoy Orellana y Contreras Cruces, 2008). Para el caso de Cuyo, finalmente, debo referir también mis propios estudios que han abordado los procesos de etnogénesis huarpe en relación fundamentalmente a la defensa de tierras de antiguos pueblos de indios en Guanacache durante los siglos XIX y XX (Escolar, 2007, $2013,2014)$. Jueces, subdelegados o comisarios locales motorizaron con relativo éxito la defensa de las tierras comunales, movilizando archivos, solicitando protectores de indios e invocando el derecho indiano y su historia reduccional a lo largo del siglo XIX.

Resumiendo, junto con la relativización de las tipologías de liderazgo y las nociones rígidas de cacicazgo, diversas investigaciones en Argentina y Chile coincidieron en señalar la persistencia hasta el siglo XIX o el XVIII tardío de estrategias y formas de liderazgo político indígena orientadas a la preservación de las tierras comunales, aunque relativizando el papel de los caciques y reconociendo la existencia de otros cargos que encabezaban eventualmente los procesos.

Para aportar al conocimiento de estar problemática, en este artículo propongo abordar la continuidad de liderazgos indígenas y la defensa de sus territorios y autonomía en Cuyo mostrando el empoderamiento de caciques a lo largo del siglo XVIII, a través del análisis de un linaje de caciques del centro-norte de la región. Se trata de los Alcani, caciques del pueblo de Mogna desde fines del siglo XVII hasta principios del siglo XIX. Esta investigación se basó en parte en información publicada en estudios previos, y también en el tratamiento de una fuente inédita que pese a su importancia para el tema hasta ahora no hemos visto mencionada por la literatura específica: los autos del juicio realizado por el regidor y alcalde provincial de San Juan entre 1801 y 1804 al cacique Francisco Alcani de Mogna. ${ }^{8}$

\section{Mogna rebelde: aboriginalidad y criollismo}

El principal argumento etnohistórico que cuestionó la presencia indígena en Cuyo a mediados del período colonial, además de la extinción o miscegenación, es la desestructuración política de comunidades y liderazgos étnicos. Por eso, suena bastante extemporáneo cuando en Recuerdos de Provincia Domingo Faustino Sarmiento, el famoso constructor de la nación y también promotor contradictorio de las narrativas de extinción y de potencial resurrección huarpe, nos dice que hasta 1830 vivió el cacique de Mogna "habiendo llegado a una senectud que pasaba de ciento veinte y más años" (Sarmiento, 1966:32). En El Chacho. Último Caudillo de la Montonera de los Llanos publicado en 1867 ratificará este dato diciendo que Mogna tenía un cacique que "vivía ahora cuarenta años" (Sarmiento, 1947: 86). Mogna era una

\footnotetext{
${ }^{8}$ Archivo de los tribunales de San Juan, Penal, Caja 3, 1700-1810. El fiscal contra Pascual Alcani cacique de Mogna, 1804.
}

localidad que el sanjuanino connotaba reiteradamente como relicto indígena en su literatura. En Recuerdos, publicado originalmente en 1850, afirmará en tiempo presente que el célebre rastreador Calibar -que en Facundo, publicado cinco años antes, representaba el arquetipo del gaucho (Sarmiento, 1963 [1845]): 8184) - " "se ha retirado a morir a Mogna, la morada de su tribu" (Sarmiento, 1966[1850] : 36) Y posteriormente, en su historia sobre el Chacho Peñaloza y las rebeliones montoneras de la década de 1860, aludió frecuentemente a la localidad como uno de los pueblos rebeldes de raigambre huarpe cuyas "venganzas indias" explicarían

(...) la especial y espontánea parte que en el levantamiento del Chacho tomaron, no sólo los Llanos y los Pueblos de La Rioja, sino los laguneros de Guanacache, los habitantes de Mogna y Valle Fértil, y todos los habitantes de San Juan diseminados en el desierto que se extiende al este y norte de la ciudad, y hasta el pie de las montañas por la parte del sur (Sarmiento 19947 [1867]: 93).

Podría pensarse (y así fue considerado) que estos tropos constituyeron una licencia romántica del autor basada en una construcción de aboriginalidad (Briones 1998) meramente narrativa y pintoresca. Sin embargo, estas escuetas y misteriosas semblanzas adquieren un anclaje histórico cuando confrontamos los datos sobre la larga defensa de sus tierras que los caciques de Mogna: Diego, Santiago, Francisco, y Juan Pascual Alcani, realizaron a lo largo del siglo XVIII y hasta principios del XIX. Nos interesa reconstruir este caso porque es tal vez el mejor documentado sobre la trayectoria de los liderazgos indígenas luego de la supuesta extinción cuyana, permitiendo vislumbrar las relaciones históricas entre los indígenas del período colonial y los emergentes "indios criollos" del siglo XIX.

Mogna es en la actualidad un pueblo con poco más de cien habitantes en el centro-norte de la provincia de San Juan, en el departamento de Jáchal (Figura 1). Su tupido bosque de algarrobos y chañares se destaca en medio de un ominoso desierto de relieve casi lunar, a más de 70 kilómetros de cualquier otro paraje habitado. El río Jáchal, proveniente de la Cordillera de los Andes, llegaba antiguamente con caudales suficientes para hacer del lugar un área relativamente fértil y con buenas zonas de pastoreo.

Mogna está ubicado en un largo valle en el curso medio del río Jáchal (antiguamente denominado río de Mogna) y dominaba la amplia y árida región llana del bolsón del Bermejo, centro-este de San Juan, desde las sierras de Mogna hasta el Río Huaco al norte, las de Valle Fértil al este y las de Pie de Palo al sur. Aunque en la actualidad el río casi no trae agua, antiguamente se encontraban allí los bañados intermitentes del río Jáchal-Zanjón y diversas 
Figura 1. San Juan en el período colonial. Mapa confeccionado por: Laura Zalazar.

Figure 1. San Juan in the colonial period. Map made by: Laura Zalazar.

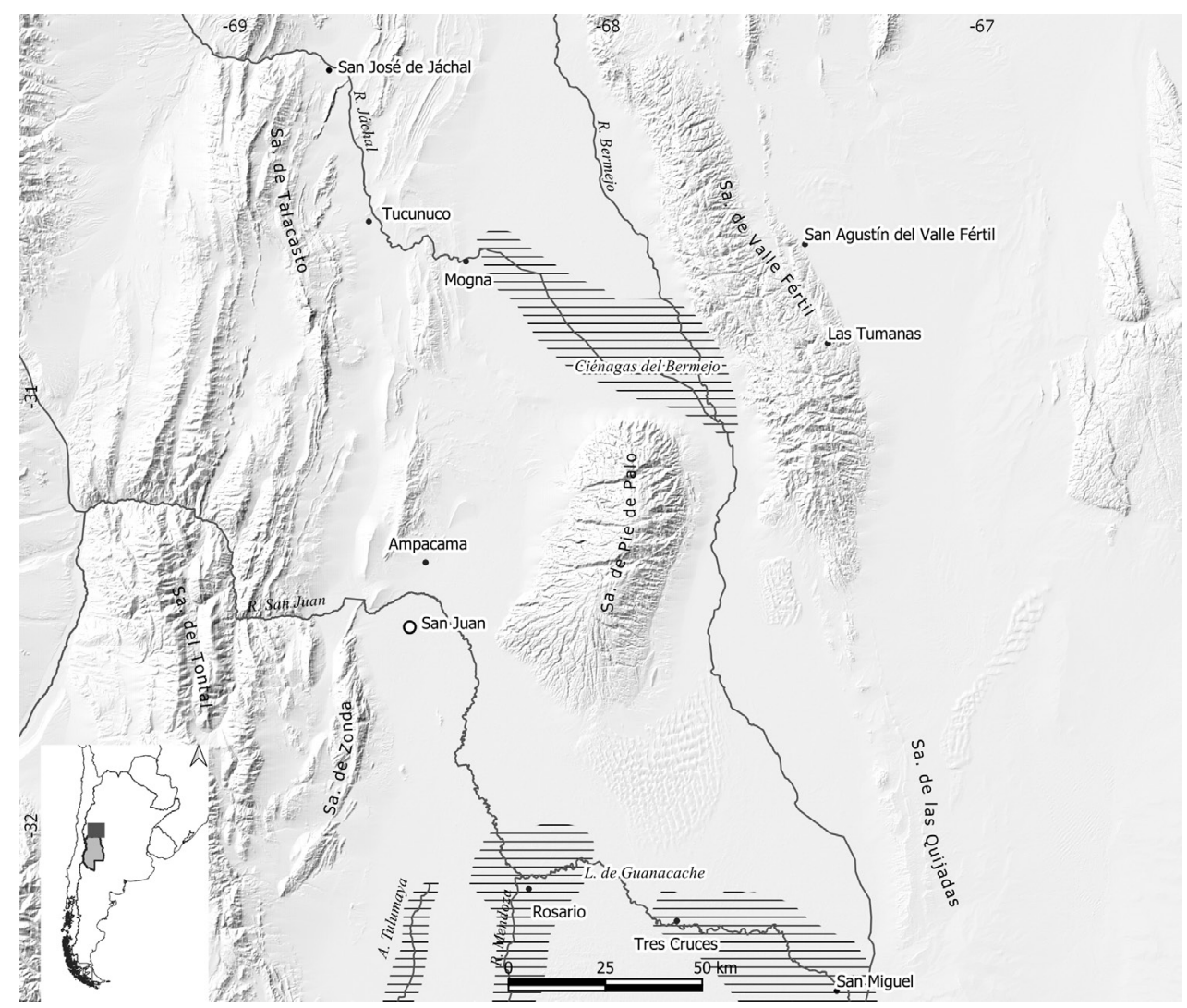

aguadas en el pie de las serranías, como de Famacoa, bajo el extremo norte de la Sierrra de Pie de Palo. Hacia los siglos XVII y mediados del XVIII poseía importantes recursos forestales y posibilidades para el riego por la altura del cauce del río. Entre el siglo XVII y mediados del XVIII, fue centro de encomiendas. Fue hasta el siglo XIX un nodo en las rutas de transporte de ganado en pie entre el área pampeana de Argentina, el Tucumán colonial y los centros mineros del norte de Chile y la actual Bolivia. Hoy, sin embargo, sus escasos habitantes dependen de un camión de agua que les envía mensualmente la municipalidad de Jáchal para subsistir.

Si nos remontamos a inicios de la colonización española veremos que sus habitantes constituyeron, junto con los indígenas del Río Bermejo y Valle Fértil, la resistencia más fuerte al dominio español en la provincia de San Juan. Entre 1630 y 1633 los aborígenes de estas áreas -clasificados como capayanes o yacampis (Canals Frau, 1956; Michieli, 2000) se plegaron al "gran alzamiento" calchaquí, matando varios españoles y avanzando hacia la ciudad de San Juan (Cabrera, 1929; Ardissone y Grondona, 1957; Michieli, 2000). La rebelión preocupó a los conquistadores quienes, según sostienen algunas investigaciones, temieron que a través de Cuyo se articulara un frente de las parcialidades del norte con los puelches y pehuenches que se desplazaban entre el Arauco y el sur de Mendoza y por la misma época amenazaban con atacar la ciudad de Mendoza. Esta inédita alianza, que agitó recurrentemente la imaginación de los españoles (Ardissone y Grondona, 1957) hubiera sido potencialmente catastrófica para el dominio colonial uniendo en un movimiento de pinzas los dos principales frentes de guerra españoles en el cono sur sudamericano. Mogna había sido el lugar de reunión previo de los indígenas del Bermejo y Valle Fértil antes de avanzar hacia la ciudad de San Juan. Luego de sofocado el alzamiento con 86 tropas españolas enviadas desde Chile, los rebeldes huyeron a Guandacol (actual provincia de La Rioja) y en Valle Fértil fueron vencidos y tomados prisioneros. Doce caciques fueron sentenciados a muerte y ahorcados; diez del Río Bermejo, uno de Mogna y otro de Valle Fértil (Cabrera, 1929: 34-36; ver también Ardissone y Grondona, 1957; Boixadós, 2007-2008). El cacique de Mogna era Juan Cantitucla "del apellido tucmangasta". Los indígenas restantes fueron repartidos en encomiendas y, como ocurrió con varios grupos luego del gran alzamiento calchaquí, gran parte fue trasladada a sitios distantes, incluso al Río de la Plata (Michieli, 2000). ${ }^{9}$ Parte de los de Mogna fueron instalados en las inmediaciones de la ciudad de San Juan y, como veremos a partir de esta investigación, probablemente en San Luis y las lagunas de Guanacache.

Según estudios de Catalina Michieli hacia fines del siglo XVII había solamente dos encomiendas con gente de Mogna. La de Joseph de Lasiar, con Nicolás Cantintucla (de la línea sucesoria de Juan Cantintucla, ahorcado 63 años atrás) y otra que reunía indios de Mogna, Valle Fértil y Río Bermejo y que tenía por caciques a Gaspar Mullmui de Mogna, Francisco Managua de Valle Fértil y

\footnotetext{
${ }^{9}$ Los del río Bermejo por ejemplo.
} 
Joseph Gualcusa del río Bermejo (Michieli, 2000: 9). ${ }^{10}$ En 1699 se mantiene sólo esta última con gente de Mogna (Michieli, 2000: 11). ${ }^{11}$ Sin embargo, estas informaciones no dan cuenta aparentemente de todos los caciques de esa procedencia. La propia Michieli (2000: 14) comenta que en un juicio de 1693 se menciona como testigo a un cacique de Mogna llamado Diego, que a la fecha tenía más de 60 años, ${ }^{12}$ quien suponemos (como veremos más adelante) que es Diego Alcani, el más antiguo ancestro conocido del linaje de caciques que trataremos. Hacia principios del siglo XVIII, según los datos reunidos por la autora sólo quedaría una encomienda en Mogna, de Juan de Oro (Michieli, 2000: 20), aunque en realidad la propia información brindada consigna indios de Mogna pero situados en Valle Fértil. No obstante estas precisiones, es probable que haya habido más encomiendas tanto localizadas en Mogna como formadas por indígenas de esa procedencia pero agrupados en otras partes de San Juan. ${ }^{13}$ Juan de Oro fue el encomendero de Diego Alcani, y según testimonio de sus descendientes, y él y su grupo habían sido trasladados varios años a San Luis y las lagunas de Guanacache, para luego retornar a Mogna una vez extinguida la encomienda (Michieli, 2000: 27).

Aunque fue refundado en 1753, en el área de Mogna existía un pueblo de indios como mínimo en 1737 y según indicios, al menos desde la segunda mitad del siglo XVII. En 1737 el cacique Francisco Alcani testificó en un juicio que habían usurpado "la fundación de mi parte y sus antecesores" en Mogna (en Michieli, 2004: 154-155). Aunque no hay datos sobre la fundación original del pueblo, en otro juicio de 1693 se le tomó declaración al cacique Diego sobre los antecedentes de los caciques del vecino pueblo de Tucunuco, a quienes dijo conocer hacía más de 60 años. ${ }^{14}$

El pasado rebelde de Mogna quedó archivado como un hito del temprano proceso de colonización de Cuyo y la historia del área y los indios que lo habitaban espera ser abordada con mayor profundidad. No es el objeto de este artículo reconstruir esa historia, pero señalaré solo algunos datos dispersos que marcan su persistente aboriginalidad y también su ejemplaridad criolla. Las menciones que podemos encontrar en algunos documentos del siglo XIX describen a sus habitantes como una chusma dedicada al abigeato y el cuatrerismo con eternos conflictos con las estancias vecinas-en particular la de Tucunuco,

\footnotetext{
${ }^{10}$ Resumen de las encomiendas registradas en la jurisdicción San Juan en 1695. Archivo Histórico de Mendoza, carp. 43, doc. 6.

${ }^{11}$ Archivo Nacional de Chile, Capitanía General, 488, f. 26-27; y 526, f. $80-113$

${ }^{12}$ Archivo Histórico de Mendoza, carp. 113, doc. 3.

13 En efecto, los datos suministrados obtenidos de diversa documentación del período 1700-1727 señalan 56 encomenderos, de los cuales solo diez indican la procedencia o el lugar de asentamiento de los indios, hecho que la autora atribuye a su localización en inmediaciones de la ciudad de San Juan (Michieli, 2000: 20-22).

${ }^{14}$ Archivo Histórico de Mendoza, carp. 113, doc. 3, f. 1- 13.
}

otro antiguo pueblo indígena cuyas tierras fueron apropiadas - por la escasa agua del río Jáchal. Hacia las décadas de 1860 y 1870 los moquineros se plegaron a los últimos levantamientos montoneros que tuvieron como epicentro La Rioja y San Juan y enfrentaron a los Doncel, dueños de Tucunuco y una de las familias más importantes de San Juan, hasta entrado el siglo XX (Casas, 2009). Mogna es referencia también de dos de los principales personajes populares de San Juan: La Martina Chapanay y Buenaventura Luna. La primera, una famosa bandolera y montonera del Chacho de origen huarpe que dominaba las rutas de tráfico de San Juan con Córdoba y Buenos Aires, que vivió en Mogna sus últimos años y cuya tumba es venerada en la localidad hasta el día de hoy. El segundo, un notorio folclorista que vivió durante su infancia en el área participando también de las expediciones y fogones de arrieros moquineros. Esta experiencia sería la base de una apuesta estética y política de reformulación popular de la identidad nacional en torno a la multiplicidad étnica y racial de los "criollos" rurales, plasmada en su famoso poema denominado, precisamente El fogón de los arrieros (Adamosky, 2019: 173-189; Gargiulo H. y Casas, J. 2006). Indios y montoneras parecen ser los tropos recurrentes de la memoria construida sobre el lugar, que en parte Luna recoge en el siglo XX y se vislumbra también en otros registros. En la imponente Encuesta Nacional de Folklore de 1921 una directora de escuela de Tamberías, del departamento de Jáchal, escribe brevísimas referencias sobre los "pueblos de Jáchal. Señala dos: Huaco, sobre el cual menciona que hubieron muchas muertes en ocasión de las "guerrillas de Varela" durante las montoneras de la década de 1860; y Mogna, sobre la que escuetamente se dice: "En este lugar es donde habitó el último cacique llamado Alcani." ${ }^{15}$ Esta alusión tan explícita no solo marca la persistente aboriginalidad atribuida a la localidad, sino que es la única referencia al nombre del cacique que he hallado luego de los autos del juicio de 1804 y una escritura de 1809. Muestra también que, a pesar de la aparente falta de datos escritos, la memoria del cacique se mantuvo vigente por más de un siglo.

La aboriginalidad de Mogna, finalmente, es parte de las memorias huarpe actuales. Paz Argentina Quiroga, Amta o dirigente huarpe de San Juan, aun desconociendo al nombre de Alcani remite su ancestría a Mogna y sus caciques luchadores. E incorpora a Buenaventura Luna como huarpe honorario al describir que, cuando su féretro viajo a Jáchal, jinetes moquineros vistiendo secretos colores huarpes lo recibieron en una emotiva parada. Con la intención de reponer parte del encadenamiento histórico de estas memorias aborígenes, avanzaremos entonces con la reconstrucción de las tribulaciones, prácticas y palabras de los caciques Alcani durante el siglo XVIII y principios del XIX.

\footnotetext{
15 Instituto Nacional de Antropología y Pensamiento Latinoamericano, Encuesta de folklore de 1921, Legajo 69 San Juan, carpeta 126 Jáchal, escuela $n^{\circ} 64$ de Jáchal, Tamberías, folio 55
} 


\section{Los pleitos de un linaje indígena cuyano}

En 1737 el Protector de Indios de San Juan entabló la defensa del cacique Francisco Alcani en contra de Carlos Aguilar, nieto del conquistador Juan de Mallea, acusado de introducir ganados y sacar madera en las tierras del pueblo de Mogna. Aguilar invocó una Merced Real a Mallea que el Protector impugnó porque sus supuestos límites no incluían las tierras del pueblo en Mogna. ${ }^{16}$ Las tierras que el cacique consideraba propiedad de "su fundación" según relación que le efectuara a su protector, eran las que corrían entre el antiguo casco abandonado de la estancia de Mallea, que distaba ocho leguas río abajo, unos 45 kilómetros, y el pueblo de Tucunuco, aproximadamente otro tanto río arriba, hacia Jáchal. El Valle de Mogna en su totalidad era estimado en 25 leguas. ${ }^{17}$

Los testigos del Protector afirmaron que el grupo de indígenas que representaba Alcani había sido encabezado por el abuelo y el padre de Francisco, los "caciques antiguos" legítimos, trasladados por su encomendero desde un paraje denominado Socoscora (San Luis) a Guanacache durante muchos años y de allí, una vez vacante dicha encomienda, regresados a Mogna, de donde serían originarios (Michieli, 2004: 27). El Protector mencionó también la existencia de una Real Provisión que la Audiencia de Chile habría expedido en favor del abuelo de Alcani, documento que no hemos hallado aún, pero es plausible si comparamos con otros casos en Chile que muestran reconocimiento de cargo a caciques una vez vacante la encomienda de servicio personal los cuales encaran la recuperación legal de las tierras originales del grupo. ${ }^{18}$

Aguilar, por su parte, intenta colocar que el cacique usurpaba el cargo y las tierras de su propio pueblo como propias. ${ }^{19}$ Afirmó que Francisco no era cacique legítimo sino que pretendía serlo y tener derechos a las tierras de Mogna por una carta de amparo que su abuelo, Diego Alcani, había obtenido para que se le restituyesen dos hijos, Santiago y Alonso, que su encomendero Juan de Oro le había quitado cuando servía en San Luis. Que

\footnotetext{
${ }^{16}$ Archivo Histórico de San Juan, Caja 4, carpeta 22, doc. 12 f.1-28.

${ }^{17}$ Archivo Histórico de San Juan, Caja 4 carp. 2 doc 12.

${ }^{18}$ Ver por ejemplo el caso del cacique Lienlieu del pueblo de Talagante

en el Chile central que fue nombrado por la Real Audiencia en 1718, al extinguirse la encomienda durante la cual su grupo sirvió en la estancia de su encomendero, vecina a las mismas, durante un siglo (Contreras Cruces, 1998: 141-142). Apenas fue designado, Lienlieu batalló con éxito por el desalojo de un ocupante español y el reconocimiento de la propiedad de los indios.

${ }^{19}$ Aunque no parece ser este el caso, existieron en Cuyo indios, en general caciques, reconocidos como propietarios individuales o que en tal carácter venden las tierras que fueron pueblos de indios, tema que es materia de otro trabajo en curso. El propio nieto de Francisco, Pascual Alcani, como veremos más adelante, aparecerá en un documento donando tierras a un español a principios del siglo XIX.
}

Diego Alcani fue reconocido como cacique pero que en realidad era un pariente colateral del verdadero cacique. También, que Francisco alegaba su cacicazgo porque su padre (Santiago ${ }^{20}$ había sido nombrado como capitán por el corregidor cuando formó compañías militares de indios con la finalidad de defender la frontera sur de Cuyo ante la amenaza de indios alzados (Michieli, 2000: 37). Esta referencia es muy importante porque podría ser un elemento legitimador de las tierras del pueblo de indios, como ocurriera en numerosas jurisdicciones coloniales y en Cuyo según una investigación que estoy realizando.

Entre 1751 y 1754 el Cacique Francisco Alcani tuvo un rol protagónico en resistir y condicionar el proceso de creación de un pueblo de indios en Jáchal que sería finalmente fundado en Mogna. En 1751 la Junta de Poblaciones de Chile, como parte de un plan general de fundación de pueblos de indios y villas de mestizos y españoles en Cuyo, notificó a los indígenas de Mogna y la vecina Ampacama que debían trasladarse a Jáchal donde el Superintendente Juan de Echegaray fundaría una Villa de españoles. El cacique Francisco Alcani resistió sucesivas intimaciones reales aduciendo que en Mogna era donde tenían sus pasturas y aguadas, con abundancia de madera y acceso a sacar agua de riego y que el cura le había encargado construir una capilla en el lugar. Además, invocando la ideología de segregación étnica colonial de las fundaciones de villas y pueblos (reforzada en la etapa borbónica) manifestó que al estar Mogna muy retirada de Jáchal evitarían naturalmente mezclarse con españoles y mestizos (Michieli, 2000: 43-49; 2004: 151-166.). Pero la principal preocupación del cacique y sus indios era evidentemente la pérdida de las tierras. Como insinuaba el cacique, tanto el superintendente como el cura impugnaron sus dichos afirmando que había muy escasa población de indios en el área, que estos estaban mezclados con mestizos. También afirmaron que el cacique no residía en Mogna y que pasaba mucho tiempo en la ciudad de San Juan. Estas explicaciones estaban al parecer teñidas por el imperativo de minimizar la presencia indígena en la región para deslegitimar sus derechos territoriales. En su informe de 1756, por ejemplo, el Superintendente Juan de Echegaray argumentaba de diversos modos (extinción, fuga, mestizaje) la escasa entidad de los indios.

"...los pobladores son yJos de. estos parajes opueblos comarcanos q lofueron quantiosos de. yndios naturales según lo demuestrran sus ruinas yestos ocon la oprrecion de. la guerra al tiempo de. la pacificacion de. esta prouincia: retirados apartes remotas o por el calor de. el español eintrroducion de. pestes: o con la trrasmutasion con el trrato de lajente española: en mestisos: cholos: y quarterones seallan casi

\footnotetext{
20 No consta en este documento el nombre del padre. Ver más adelante, la genealogía de los Alcani reconstruida por el hijo de Francisco, Pascual.
} 
de el todo estingidos de. indios lexitimos estos parajes ypueblos: de. modo q estas especies de. Jentes originarios de los mesmos yndio gosan el titulo de. mestisos españoles q abitaban aquellos terminos dispersos endonde acada Vno le parecia conueniente Manteniendose de. sus labrransas de. trrigo: mais: papas: y quinua: yalgunos ganados maiores ymenores: ybicunas: guanacos carne silbestrre q abunda en las cordilleras ysus faldas y demas legunbrres q cultiuan mas albigor de. la tierra q asuindustrria y trrabaJo..." (Michieli, 2004: 46). ${ }^{21}$

La constante manipulación a la baja de las cifras de indígenas al igual que su caracterización como mestizos, vagos y ladrones, más allá de la creciente presencia de agregados, soldados o sujetos tipificados como "mestizos"22, estaba destinada a deslegitimar sus demandas o defensas territoriales. Sin embargo, el propio discurso de Echegaray muestra contradicciones evidentes. Primero, coloca como evidencia gráfica de su extinción la existencia de ruinas abandonadas de construcciones donde habrían habitado. Inmediatamente esto es relativizado al afirmar que los indígenas no desaparecieron sino que las abandonaron y se desplazaron a lugares remotos por la guerra, las pestes y la opresión coloniales. A continuación también se relativiza la fuga de los indios y se plantea que en realidad se transmutaron en mestizos, cholos y cuarterones por su contacto con españoles. Este contacto parece aludir más a un cambio social que biológico: "Jentes originarios de los mesmos yndio gosan el titulo de. mestisos españoles". En este sentido, con dos siglos de diferencia, la metáfora alquímica de la "transmutación" del indio en mestizo español del superintendente Echegaray, la alquimia de la "disolución" del indio desarrollada por la propia Michieli y otras explicaciones ensayadas sobre la supuesta extinción indígena en la región, corren por similares carriles. En efecto, los principales puntos por los que se infiere la "disolución" de los indígenas (y por lo tanto la legitimidad de sus demandas) es la falta de cumplimiento de requisitos jurídicos del sistema colonial para clasificar un sujeto como indio, el mestizaje o el grado de "pérdida" de su cultura original. Sin embargo, como vemos en los mismos expedientes, ninguno de estos aspectos pareció significativo a la hora de reconocer el status y derechos esgrimidos por los caciques por la Real Audiencia.

La resolución del caso evidencia que, al menos para la época, los alegatos del cacique fueron más efectivos que los de los del cura y el superintendente. La reiterada negativa del cacique a trasladarse a Jáchal con sus sujetos determinó que, a su solicitud, se fundara un pueblo de indios propiamente en Mogna, e incluso en este caso,

\footnotetext{
21 Archivo Nacional de Chile, Real Audiencia, 2907, f. 129.

22 La bibliografía es abundante a este respecto para Argentina y Chile. Ver por ej. Farberman, 2009 para un excelente análisis en Santiago del Estero.
}

en el lugar reclamado por el cacique y no en el sitio que había sido previamente señalado por las autoridades coloniales. En agosto de 1753 se formó el pueblo en Mogna par la colectividad de indios según auto del teniente de gobernador Eusebio de Lima y Melo, trazando las cuadras y repartiendo solares, señalando los ejidos comunes y las tierras para chacras $Y$ tres días después se efectivizó y legalizó la posesión en la persona del cacique (Michieli, 2004: 49). ${ }^{23}$

Los conflictos sin embargo no cesaron y podemos observar su continuidad, a la vez que de los argumentos, prácticas y resoluciones judiciales mencionadas. En 1763 Asencio Balmaceda hizo detener a Francisco Alcani, dos de sus hijos, dos niñas y un niño (op. cit. 37). ${ }^{24}$ Alcani presentó un reclamo a la Real Audiencia en Santiago a través de su fiscal, que actuó como defensor de indios, alegando que había sido detenido en prisión y maltratado por más de veinte días junto con dos de sus hijos por instigación de Balmaceda, quien quería usurpar sus tierras. En el testimonio tomado al cacique por el Protector General de indios éste informó que mientras estaba realizando diligencias en la ciudad de San Juan fue aprehendido por el teniente de justicia de la ciudad y encerrado un mes "en el calabozo más oscuro" sin informar el cargo ni tomarle declaración. Que a los veinte días de estar preso trajeron dos de sus hijos "amarrados de pies y manos" más las dos jovencitas y un niño, además de tomarle 20 caballos. Y que a raíz de esas acciones los indios varones abandonaron el pueblo, ganado y cultivos dejando a sus dos hijas solas. Alcani sostuvo que la denuncia y hostigamiento de Balmaceda tenía como objeto atemorizarlo para que abandonara el pueblo y así poder usurpar sus tierras "que a fuerza de castigo o rigor quedarse con dichas tierras, y que compelidos dejemos dicho pueblo desierto." (Michieli, 2000: 38). ${ }^{25}$ Posteriormente el cacique declaró que habiendo el Teniente de Justicia liberado a él y a uno de sus hijos para que volvieran a Mogna, Balmaceda dijo que permanecieran en la ciudad de San Juan hasta que llegase la causa que había remitido a la Real Audiencia, alegando que "Tenía facultad de los Señores Presidente y Oidores de esta Real Audiencia para aprehender a todos, y que le reconozcan por juez..." y que "si pretendemos venir a esta Ciudad (Santiago), nos habrá de pasear por las calles prometiéndonos azotes, y temerosos de no experimentar más vejámenes nos pusimos en vía de esta ciudad a buscar Justicia dela que carecemos en esa Ciudad (San Juan)." Resulta notable la aparente facilidad y familiaridad con que Alcani viajó a Santiago para acudir a la Real Audiencia, como al menos su abuelo Diego Alcani había procedido y es probable que tuvieran lazos en aquella ciudad. Sin embargo, parecen haber sido más habituales de lo esperable los viajes por parte de los indígenas a

\footnotetext{
${ }^{23}$ Archivo Nacional de Chile, Real Audiencia, 2907, fs. 228-232.

${ }^{24}$ Archivo Histórico de San Juan, caja 10, carp. 46, doc. 5, f. 2

${ }^{25}$ Archivo Nacional de Chile, Capitanía General 522, f. 228-230
} 
las sedes de la Real Audiencia para demandar o hacer seguimientos de causas y cumplimiento de sentencias. ${ }^{26}$ Hay un indicio más, no concluyente, que podría abonar la idea de una relación duradera de los Alcani con Chile, o tal vez con indígenas de habla mapuche, en esta misma ciudad pero también en la frontera sur. Cuando refiere que Balmaceda hace apresar a sus dos hijos y dos hijas pequeñas agrega que también le quitaron "un güeñicito de menor edad". El término derivado de hueñi, mapuche, por niño pariente o dependiente, hace pensar en la adopción de lengua mapuche por una estadía prolongada en aquella jurisdicción. También podría deberse, claro está, a la relación de Santiago Alcani con los puelches cuando realizó servicios militares como capitán de amigos en la frontera sur de Mendoza (Michieli, 2000:36).

Finalmente, al Real Audiencia ordenó la libertad de Alcani junto con la restitución de caballos y parientes más la prohibición a Balmaceda de tener contacto con la gente de Mogna bajo penas de multa, destierro y prisión.

Resultan notables algunas semejanzas de las prácticas coloniales contra los caciques comparando con lo ocurrido con el abuelo de Francisco, Diego Alcani, según senarra en el juicio con Aguilar en 1737. A ambos les fueron sustraídos sus hijos como medio de presión, por parte de su encomendero en el primer caso y por un terrateniente en el segundo y en ambos casos la Real Audiencia de Chile los amparó frente a los antagonistas españoles locales. Sin embargo, la interpretación de estos documentos por parte de Michieli sugiere la persistencia de una fuerte mirada colonial a pesar de algunos datos que dichas fuentes y ella misma ofrecen. Aunque alude-sin mayor análisis-al carácter irregular de los derechos reclamados por Balmaceda y otros familias descendientes de conquistadores basados en la imprecisión de las Mercedes Reales de tierras otorgadas, ${ }^{27}$ su énfasis está colocado en impugnar la legitimidad de los derechos indígenas. Haciéndose eco de los argumentos de los denunciantes de Alcani, y a pesar del reconocimiento de su cacicato por la Real Audiencia en todos los juicios, plantea que Alcani no podía demostrar la legitimidad de su cargo porque el apellido no aparecía en la documentación del siglo XVII y principios del XVIII. Esta postura hace caso omiso de los propios datos proporcionados por ella a partir de los documentos analizados. Llega a desestimar la mención en un documento de 1693 de un cacique "Diego" del pueblo

\footnotetext{
${ }^{26}$ Los indios del pueblo de San Marcos, en Córdoba, acudieron trece veces (tres de ellas su cacique, Tulian) a presionar por la concreción de una orden de mensura de sus tierras (Tell, 2010). Algo similar destaca Rodríguez $\left(2011^{\mathrm{a}}\right)$ con el mítico viaje a Buenos Aires del cacique de Amaicha, Don Lorenzo de Olivares, y Robledo y Chumbita para el cacique de Aimogasta, José Francisco Chumbita, en La Rioja, que en 1803 "bajó con sus papeles y razones hasta Buenos Aires a reclamar directamente al Virrey Del Pino que se les hiciera justicia" (Chumbita y Robledo, 2011: 31).

${ }^{27}$ Cita el caso de la familia Mallea -de la cual se afirmaba descendiente Domingo Faustino Sarmiento - que esgrimiendo una Merced de 1593 durante el siglo XVIII litigó por tierras en Mogna y los actuales departamentos de Albardón y Angaco (Michieli, 2004: 38).
}

de Mogna, de más de 60 años de esdad, por el hecho de que no consta su apellido (Michieli, 2000: 38), ${ }^{28}$ cuando es demasiado probable que se trate del mencionado Diego Alcani, abuelo de Francisco, quien figura con su nombre tanto en el testimonio de Francisco Alcani como en el de Aguilar, y que había obtenido una Real Provisión de la Audiencia de Chile (Michieli, 2000: 27). ${ }^{29}$ En suma, estos análisis parecen no poder sustraerse de la posición autorial, ideológica y argumentación de los españoles que litigaban contra los indígenas por sus tierras.

Un documento que he recabado permite reponer en parte el discurso histórico y las prácticas de los caciques de Mogna y observar la continuidad de este linaje y sus políticas hasta principios del siglo XIX. ${ }^{30}$ Se trata de un juicio realizado entre 1801 y 1804 al cacique de Mogna Pascual Alcani por robos de ganado y cargas. Resulta interesante reponer con cierta extensión el desarrollo de este juicio ya que permite observar la vigencia de conflictos interétnicos en la región hasta los inicios del proceso independentista y algunos aspectos importantes de la experiencia indígena: las prácticas de resistencia territorial y judicial, las características del liderazgo de los caciques, la relación con sus sujetos y las autoridades coloniales y las memorias sobre el grupo y sus antepasados. No se trata del único cacique cuyano del que tenemos noticias para la época. También los caciques Puscama de Valle Fértil, que condicionaron el proceso de formación de la Villa de Valle Fértil y Joseph Semeyan, de Corocorto, en Mendoza, que pleitearon por e reconocimiento de sus tierras y cargos hasta al menos le primer década del siglo XIX. Pero esa historia será tratada en otros trabajos en curso.

\section{Juan Pascual Alcani: el veterano de los "últimos caciques" sanjuaninos}

En octubre de 1801 el alcalde regidor de la ciudad de San Juan Don Juan Rufino, de visita en Jáchal, acudió junto con el vicario de esa Villa al pueblo de Mogna para aprehender al cacique e instruirle una causa sobre robos de ganado y no observar los sacramentos, confesiones y comuniones. Pero no lo halló porque había huido con su familia al monte. ${ }^{31}$ Prontamente sin embargo el cacique se presentó y fue puesto en prisión para iniciarle proceso, el cual comenzó en el mismo lugar con el levantamiento de una información con testigos.

Las primeras acusaciones del regidor apuntaron, con una exasperación que alcanza a emanar del texto, a denunciar la fuga del cacique y los sospechosos (en realidad todos los varones y algunas mujeres del pueblo) a raíz de haberse enterado de que él venía a interrogarlo. Respondiendo

\footnotetext{
${ }^{28}$ Archivo Histórico de Mendoza, carp. 113, doc. 3, f. 1- 13

${ }^{29}$ Archivo Histórico de San Juan, caja 4, carpeta 22, doc. 12 f.1-28.

${ }^{30}$ Archivo de los tribunales de San Juan, Penal, Caja 3. El fiscal contra Pascual Alcani cacique de Mogna, 1804.

${ }^{31}$ El fiscal contra Pascual Alcani... op. cit.
} 
a las preguntas del regidor varios testimonios detallaron robos de ganado en Jáchal, Valle Fértil, Las Tumanas, Aguango y Tucunuco por parte de los indios de Mogna. Si bien se detallan diversos hechos los principales fueron practicados al estanciero de Tucunuco, Domingo Jacome. Alejandro Puscama, de Valle Fértil, sembrador y cuidador de tropas de mulas, menciónó el robo de una vaca a la mujer del estanciero, el cual su autor "después se compuso para pagarle". ${ }^{32}$ Se acusó al cacique Alcani, que ya había estado en prisión, de participar del mismo. ${ }^{33}$

...cuando el mencionado cacique salió de la prisión en que lo tuvieron en San Juan y se vino a su pueblo y mandó juntar a sus indios diciendo los quería poner en orden y a los dos días fueron dichos indios a la Ciénaga y se trajeron dos vacas de este declarante y se las comieron en compañía de dicho cacique y después de habérseles acabado dieron tras de los novillos que tenía Don (...) en poder de este declarante y se comieron uno. ${ }^{34}$

Otra acusación recurrente, instigada por las preguntas del regidor y seguramente del vicario de Jáchal allí presente, era que el cacique no observaba los sacramentos y no traía al vicario para confesar a su gente por no querer costear el traslado.

le respondía dicho cacique que no tenía obligación de mandar traer a dicho señor vicario que él tenía obligación de costearse para venir al pueblo a confesar la gente ${ }^{35}$

Otro testigo ratificó que el cacique no se confesaba ni hacía confesar a su gente desde hacía tres años (aunque algunos sábados concurría a la capilla a rezar el rosario) y que no llamaba al cura porque no quería que venga. ${ }^{36}$ Luego de los testimonios incriminadores se tomó declaración a Juan Pascual Alcani, quien interrogado sobre sus datos personales dijo que su "empleo" era el de cacique del pueblo y su ocupación labrar y sembrar tierras. ${ }^{37} \mathrm{El}$ regidor le preguntó por su nombre y origen y los de cada uno de sus ancestros por línea paterna. El cacique respondió que su nombre era Juan Pascual Alcanis, natural de Mogna; que su padre había sido Francisco Alcanis, también natural de Mogna; que su abuelo Santiago Alcanis, de Mogna; y su bisabuelo Diego Alcanis, del paraje denonimado Caballactuca ${ }^{38}$. Don

\footnotetext{
${ }^{32}$ El fiscal contra Pascual Alcani, f. 7.

33 Lamentablemente no hemos encontrado las actuaciones de ese caso.

34 El fiscal contra Pascual Alcani, f. 6.

${ }^{35}$ El fiscal contra Pascual Alcani, f. 6.

${ }^{36}$ El fiscal contra Pascual Alcani, f. 7.

37 El fiscal contra Pascual Alcani, f. 8.

38 Este último término es poco legible. En el documento consta

"Alcanis" cuando se le toma declaración al cacique y este firma "Alcanes". (f. 10). Sin embargo, en todos las demás fuentes y en este mismo documento figura como Alcani, por lo que mantenemos esta rafía.
}

Pascual dijo que su bisabuelo había obtenido el cacicazgo de la Real Audiencia de Chile "adonde ocurrió a solicitarlo por haberse disgustado con su amo Don Juan de Oro a quien le servían en encomienda y se le pagaba. Y pagó tributos, hasta el tiempo que estuvo de corregidor de la ciudad de Mendoza Don Juan (...). Pero que no sabe la causa que hubo para que se suspendiera dicho tributo." Afirmó también que Juan de Oro tenía la encomienda en la Punta (actual provincia de San Luis) en el paraje San Lorenzo "donde le servían en todo lo que los ocupase."

Resulta notable como ochenta años después el hijo de Francisco, Pascual Alcani, reconstruía su linaje y el recorrido histórico, exactamente igual que su padre en aquel juicio, remontándose hasta Diego Alcani y complementando algunos datos. Recordaremos que en el pleito de 1737 contra Francisco Alcani, Aguilar había mencionado una carta de amparo que el abuelo de éste, Diego Alcani, había obtenido amparo de la Real Audiencia de Chile para que se le restituyesen sus hijos Santiago y Alonso, que su encomendero Juan de Oro le había quitado cuando servía en San Luis. En esa misma causa Francisco dijo que habían estado trasladados por su encomendero en Socoscora, San Luis, y luego en Guanacache y de allí, vueltos a Mogna (Michieli, 2000: 37).

Pascual basa la legitimidad de Diego Alcani en una designación de la Real Audiencia de Chile. Alude, al igual que su padre en 1737, al enojo de Diego con su encomendero (que según aquel juicio había sido causado por el secuestro de sus hijos) como el motivo por el cual éste solicitara personalmente el cacicazgo. Y podemos confirmar ahora el lugar de San Luis donde fueron desnaturalizados: Socoscora, señalado en el juicio de 1737, es el nombre de un río y una sierra en el actual paraje San Lorenzo que menciona Pascual, muy cercano al pueblo de San Francisco del Monte de Oro y de las antiguas minas de oro de La Carolina.

Preguntado por quiénes son los indios que tiene en su pueblo, respondió dando el nombre de quince, afirmando que estaban trabajando en San Juan trabajando ${ }^{39} \mathrm{El}$ regidor le preguntó sobre si otros cinco, que eran los acusados no pertenecían también al pueblo y responde que "se le habían olvidado el nombrarlos" y que serían los escapados por la venida del alcalde regidor. ${ }^{40}$ Alcani admitió también, luego, que habían echado sus caballos por delante en la huida. Sólo reconoció un robo, de un sujeto que un vecino había mandado a la cárcel en San Juan.

Le preguntó por qué huyó con su familia el día de su llegada y respondió que la familia de miedo, pero que él "había ido a campiar animales que tiene a su cargo". Hacía tres años que Alcani no se confesaba, desde que lo hizo en San Juan, y no había llamado al vicario de

\footnotetext{
${ }^{39}$ El fiscal contra Pascual Alcani, f. 8-9.

${ }^{40}$ El fiscal contra Pascual Alcani, f. 9
} 
Jáchal para viniera a su pueblo. "Porque no ha tenido ninguna persona de su satisfacción". El regidor lo acusó de haber consentido delincuentes pero respondió que siempre que había llegado alguien de esa clase lo había echado. Luego lo acusó de varios robos de sus indios, en especial al estanciero Jacome de Tucunuco y de no haber devuelto "una china que se tuvo robada un indio llamado Juan Aguilera alias el Chueco". ${ }^{41}$ Negó asimismo que un muchacho llamado José Javier Zelan robara una carga de higos a un viajero que iba para Jáchal, y afirmó que éste y su hermano la encontraron en el suelo y al sacar unos higos apareció un arriero que se lo llevó preso. Alcani dice haber ido con cuatro o cinco indios dispuestos a recuperar al muchacho, pero que lo encontró en Tucunuco porque ya lo habían largado. Alcani culmina diciendo que no tiene más que agregar o quitar, que es de 67 años y firma de su puño y letra el documento.

La sumaria continuó en Jáchal en 1802. El regidor Juan Rufino había puesto en la cárcel de San Juan a dos de los acusados "por los diferentes daños que [los indios] ocasionan en las estancias vecinas y en los caminos contra los traficantes" ya que "no han depuesto su mala vida sino que continúan (...) en el robo y otras iniquidades de que siempre han sido sindicados". ${ }^{42}$

Según los testigos, uno de los acusados, Páez, había robado un caballo de San Juan y luego de encontrarse con el cuidador de la tropa de mulas de Don Antonio Aberastain, el cacique Alcani con Alejandro Puscama mataron dos novillos y el cacique se llevó otro a su casa. Que el cacique se ausentó con los acusados y varios indios más porque sabía que el regidor venía de San Juan y que era público y notorio que un grupo de indios con sede en Mogna se mantenían del robo de animales de todos lados y que el cacique lo toleraba. ${ }^{43}$

Más de dos años después, en mayo de 1804, el juicio es retomado en San Juan. El regidor y alcalde provincial se refirió a las continuas quejas que desde que asumió el cargo escuchó contra Pascual Alcani "que se denomina Cacique del Pueblo de Mogna" y sus allegados "por su constante vicio en el robo, y de los demás excesos de que comúnmente abunda entre las gentes del campo y en una gente como aquella que vive sin religión". Dijo que había efectuado repetidas visitas, que los había exhortadp privadamente y también los había puesto en juicio "sin haber podido adelantar este fin por la fuga y desparramo de ellos sin haber podido adquirir noticia de su paradero". ${ }^{44}$ Que puestos en prisión dos de ellos, fugaron y que el cacique también estuvo profugo durante quince meses.

Según el alcalde hizo constar la aprehensión del cacique y el reinicio del juicio ante la Real Audiencia más de

\footnotetext{
${ }^{41}$ El fiscal contra Pascual Alcani, f. 10.

42 El fiscal contra Pascual Alcani, f. 11.

${ }^{43}$ El fiscal contra Pascual Alcani, f. 11-12.

${ }^{44}$ El fiscal contra Pascual Alcani, f. 13.
}

un año después, se produjo porque el cacique fue a la ciudad de San Juan a rescatar una india que el regidor había llevado de Mogna, supuestamente por haberla encontrado amancebada, y dado a una vecina "para le diese enseñanza". ${ }^{45}$ No obstante el secuestro de la india-tal vez alguien cercano al cacique, también puede haber sido un medio que utilizó el regidor para lograr atraerlo a San Juan.

El 8 de Junio continuó la causa y el alcalde provincial repitió, como lo hará en cada instancia, la misma fórmula desde la primera sumaria, preguntando nombre, edad, profesión, quién lo prendió, si sabe por qué, etc. El cacique afirmó que "lo puso preso el alcalde provincial, que está presente, que no tiene presente el día, pero le parece harán ya como veinte días que está preso cuya causa ignora y ni aún lo presume" ${ }^{46}$

El Alcalde entonces volvió a interrogarlo por los diversos robos y las quejas recibidas pero Alcani admitió solamente haber recibido quejas sobre daños del mismo Jacome. ${ }^{47}$ El Alcalde le señaló que no podía ignorar los muchos robos que constaban en la sumaria y que los jueces ordinarios le habían hecho pagar. Alcani admitió que el indio Páez pagó un novillo que robó a Francisco Arroyo, hacía mucho tiempo.

El 13 de julio continuó el interrogatorio y Alcani volvió a responder lo mismo, frente a las mismas preguntas y que ignoraba la causa de su prisión. El alcalde volvió a detallar y preguntar sobre los delitos imputados y actuaciones realizadas. Alcani respondió que sólo una vez fue mandado por el alcalde de primer voto Echegaray que hiciese satisfacer por Javier Zelan una vaca que había robado al presbítero Don Francisco Cano, y que no tenía otras noticias de robos cometidos por sus indios. El alcalde, evidentemente contrariado, preguntó que "cómo puede negar saber de robos si él mismo admitió que le dieron parte de que robaban a Domingo Jacome y también que Echegaray le reconvino de que Mariano Páez satisficiere un novillo robado a Francisco Arroyo". Respondió "que no tiene dicho ni declarado semejante cosa". Pero preguntado de nuevo si cuando se le tomó declaración, dijo que había recibido el papel de Jacome sobre que sus indios le robaban, etc., responde que es cierto, que lo declaró así. ${ }^{48}$ Reconvenido sobre cómo confesaba la noticia dada por Jacome cuando antes lo había negado, dice que no lo había declarado y "que no falta a la verdad" conforme lo había dicho en aquella pregunta".

Siguieron acusaciones y negaciones: preguntado "por qué ha dado permiso a cualquiera forastero o malévolo que residiese en su pueblo, dice que no ha consentido más que a la familia de Olivares que antes moró en Jáchal, a

\footnotetext{
45 El fiscal contra Pascual Alcani, f. 14.

${ }^{46}$ El fiscal contra Pascual Alcani, f. 14.

${ }^{47}$ El fiscal contra Pascual Alcani, f. 15.

${ }^{48}$ El fiscal contra Pascual Alcani, f. 16.
} 
José Gordillo, a Mauricio Muñoz y a Gregorio Managua quien ya está retirado. Preguntado cómo dice que no ha consentido pícaros cuando sabía que Gregorio Managua tenía delito de muerte, dice que es cierto, pero que él qué le había de hacer". Luego, la autoridad cierra los autos siendo leída el acta a Alcani, no agrega ni quita nada.

El 28 de septiembre, el alcalde volvió a preguntarle exactamente lo mismo, iy Alcani respondió igual! "que no tiene presente el día de su prisión e ignora la causa de ella como lo tiene ya dicho en su declaración"49 Rufino preguntó nuevamente que si sabía los daños que sus indios hacen a los vecinos y "los robos que hacen en los caminos", etc. El cacique respondio "qué jamás ha llegado a su noticia los daños que se le preguntan han hecho sus indios y que por esto no les ha dado corrección alguna."

El Alcalde preguntó que cómo negaba haber mandado a Páez que satisficiere a Francisco Arroyo, responde que no había Paez, sino Xavier Zelan quien robó el novillo y que incontinenti mandó pagar diez pesos a Arroyo. Preguntado nuevamente si es cierto que consintió a Gregorio Managua, siendo un delincuente, dice que sí, que

...es cierto que ha vivido Gregorio Managua en su Pueblo solo por haber venido y no lo echó porque la autoridad, respetos y fuerza del declarante no son bastantes para echarlo, y que ya al presente se ha ido, por conocer que no era voluntad del declarante el que morase allí por ser hombre malo.

El mismo día el defensor de menores y pobres interpuso un oficio pidiendo la excarcelación con fianza diciendo que su pobre representado está preso hace más de cuatro meses, que se encuentra enfermo, desnudo, y sin ninguna asistencia, por lo que "pide que el juzgado se conduela de sus padecimientos mirando que la orfandad de este infeliz va cada día acrecentándose así porque no tiene asistencia ninguna, como por hallarse muy distante de los suyos". ${ }^{0}$ Acompañaba la carta de Alcani pidiendo por su avanzada enfermedad y edad que no le permite valerse, firmada por su mano trémula. Se le concede la excarcelación.

Aunque el patetismo de la descripción del defensor de pobres sobre la situación carcelaria de Alcani -que coincide con lo que en general padecían los indios presos (Prieto, 2000) — podría llevarnos a concluir una típica historia de acoso, el largo y exasperante trámite del juicio parece mostrar que el cacique tenía capacidad para eludir el castigo que se le pretendía infligir. A pesar de la insistencia del alcalde regidor, la abundancia de testimonios incriminatorios y la actitud inicial de fuga del cacique en la cara del Alcalde en 1801, Alcani sólo estuvo

\footnotetext{
${ }^{49}$ El fiscal contra Pascual Alcani, f. 17

${ }^{50}$ El fiscal contra Pascual Alcani, f. 19.
}

preso esos cuatro meses durante las actuaciones de 1804 y no recibió otra pena. Nunca tuvo sentencia definitiva, al parecer porque no pudo obtenerse la confesión del cacique quien siempre negó su responsabilidad en los delitos. Sin embargo, sus declaraciones están llenas de contradicciones que prácticamente, según el alcalde parece querer evidenciar, rozan la burla. Alcani parece admitir buena parte de las acusaciones, para luego desdecirse a la hora de expresar su confesión en forma definitiva. Cada reanudación de su declaratoria vuelve a negar los cargos. Es posible también que la misma razón que motivó su excarcelación fuera uno de los factores que permitieron traerlo a San San Juan preso: su debilidad y enfermedad. La primera sumaria fue efectuada en Mogna y el juicio en San Juan tres años después.

Pero al parecer la enfermedad no mató a Juan Pascual Alcani, y es probable que haya sobrevivido hasta 1830, cuando según Sarmiento todavía existía un cacique de Mogna que pasaba de 120 años. Más allá de la probable exageración del famoso sanjuanino, Pascual declaraba 65 años en 1804, con lo cual tendría 91 en 1830 y fácilmente podría ser el cacique referido en Recuerdos de Provincia y en la Encuesta Nacional de Folklore, o incluso un sucesor del cual desconocemos su nombre. Pero la edad supuesta por Sarmiento para el cacique coincide con la que podría tener Francisco, el gestor de la fundación del pueblo de Mogna en el siglo XVIII, de estar vivo aún. Con lo cual la transmisión generacional de las tradiciones y memorias de lucha encontraría un único eslabón entre los siglos XVIII y XIX.

\section{Conclusión}

Si bien la literatura especializada ha tendido a ignorar o minimizar la presencia indígena y sus derechos territoriales en Cuyo durante el período tardo-colonial, existen antecedentes que nos muestran una larga lucha por mantener y reforzar su acceso y control de la tierra y su reconocimiento oficial.

Después de la represión de 1632, los indios de Mogna fueron encomendados, repartidos y desnaturalizados en otras partes de San Juan, probablemente cerca de la ciudad y tal vez en Chile. Sin embargo desde una fecha imprecisa de la segunda mitad de siglo XVII encontramos en Mogna un cacique Diego que probablemente sea el primer Alcani registrado cuyo bisnieto Pascual mantendría el cacicato hasta principios del siglo XIX. Entre 1701 y 1727 junto con indios de Valle Fértil, Bermejo y tal vez Calingasta fueron reagrupados en lo que sería la última encomienda sanjuanina, de servicio personal, de Juan de Oro. En ese lapso fueron destinados en San Luis y luego en Guanacache, para retornar a Mogna, aparentemente cuando se extingue la encomienda. También en ese período Santiago Alcani, hijo de Diego, obtuvo grado militar y reclutó indios para combatir en la frontera sur de Cuyo por orden del Corregidor. 
Los Alcani parecen haberse empoderado por la política fronteriza para obtener o reforzar su asentamiento o reasentarse en un pueblo, con tierras propias y con un importante grado de autonomía, en un territorio bajo permanente disputa con miembros de la elite colonial. En este respecto, en los diversos juicios que trascendieron el plano local los Alcani tuvieron en general la aprobación de la Real Audiencia de Chile, a la que parecen haber acudido en más de una oportunidad y tal vez apoyo en sectores de la elite colonial en Chile y San Juan. Cierta terminología en lengua mapuche que fue escrita en testimonios tomados a los Alcani podría indicar experiencias de convivencia con indígenas que la hablaban en la frontera sur o bien en Chile.

Resulta notable la capacidad de los caciques para negociar y reforzar su autonomía, sea presionando y defendiéndose legalmente, o aprovechando las necesidades políticas y geopolíticas de los españoles, sus conflictos intestinos o interjurisdiccionales o su debilidad territorial mediante vías de hecho, como prácticas de dilación, sabotaje, robo y fuga y dispersión. Esta capacidad de sostener poder y autonomía sobre un espacio físico y social se dio tanto en el orden jurídico como en la práctica, y puede ser interpretada como una capacidad territorial que disputa a Mogna y un amplio entorno como un territorio, con distintos grados de control, más que como un mera propiedad legal. Como ejemplo de lo primero, encontramos la negociación por la fundación o refundación del pueblo de Mogna. Las medidas borbónicas de la Junta de Poblaciones de Chile por un lado procuraban limitar estas condiciones, pero en la práctica en algunas áreas parecen haber favorecido el poder de los indios.

en donde los indios terminaron definiendo un lugar con características opuestas a las buscadas originalmente por los españoles. En lugar de su traslado a un sitio propicio para su vigilancia, potencial explotación y expropiación junto a la villa de Jáchal, mantuvieron sus tierras originales en Mogna obteniendo además el status legal de pueblo de indios que a la postre reforzó sus derechos frente a los españoles vecinos. También, antes y después, resistieron las embestidas judiciales y pudieron ejercer un control físico sobre el área y la producción ganadera sobre un amplio circuito de movilidad en el bolsón de Bermejo, entre el río Jáchal y las estribaciones de las sierras de valle Fértil.

Los Alcani mantuvieron una constante disputa contra los estancieros españoles en un amplio radio y contra los estamentos coloniales locales, incluyendo la iglesia. Sus acciones socavaban el control gubernamental y defendían intereses propios y de sus comunidades, enfrentando represalias de distinto orden, judiciales y de hecho. Pese a ello, los caciques persistieron en desafiar a las autoridades y desarrollaban estrategias de disputa del poder territorial, que aparentemente les pertenecía.
La relación que los caciques del período establecían tanto con las autoridades coloniales como con sus sujetos parece haber sido, no obstante, compleja y volátil. Los caciques ostentaban una cierta representación de sus sujetos pero también se sostenían en un reconocimiento a regañadientes por parte de las propias autoridades coloniales, quienes claramente no controlaban el área y sus poblaciones. Recurrentemente, en un aparente intento por parte del alcalde regidor de relativizar el cargo, los autos de 1804 transcriben que Pascual Alcani "dice ser cacique". Esto nos muestra por un lado que es el propio Alcani quien insiste en ser el cacique de Mogna. Por el otro, permite ver cómo a lo largo del juicio es el mismo regidor quien se resigna a aceptar este papel. El propio cacique, por su parte, sustenta su rol colocándose como mediador político con sujetos díscolos y peligrosos, en el marco de una debilidad del estado de establecer un control eficaz. Pero paradójicamente, parece afianzar también su reconocimiento gubernamental precisamente en su endeble autoridad. Como hemos citado, en una de las tantas acusaciones de albergar un criminal, responde al regidor que no lo había podido expulsar "porque la autoridad, respetos y fuerza del declarante no son bastantes para echarlo."

El cacicato en Mogna en el período, entonces, no parece fruto de una designación burocrática o instrumental y el reconocimiento del cargo parece derivar de la doble debilidad del propio poder del cacique hacia su grupo y del estado de ejercer algún tipo de control. Aunque desde luego el cacique, maestro de la ambigüedad, puede esgrimir su supuesta debilidad para exculparse por sus acciones o las de sus subordinados.

Como ilustraba Boixadós (2008) en el caso de los caciques de Malligasta, para los Alcani parece haber sido crucial el reconocimiento por parte de la Real Audiencia de Chile y la argumentación de la legitimidad linaje, incluyendo la probable producción de una memoria genealógica, aunque hay elementos que permiten observar que esta memoria no eran una mera creación sino también una forma de articulación de la memoria colectiva del grupo en torno a la confrontación con los diversos estamentos coloniales por el sostenimiento de sus tierras.

Párrafo aparte merecen las habilidades retóricas y la evidente experiencia judicial de los caciques. Una de las características más notables del auto de 1804 es el modo en que Alcani manipula sus declaraciones para evitar ser inculpado o burlarse de las resoluciones judiciales, dilatando el proceso y confrontando con el regidor quien constantemente lo acusa de mentirle en la cara. Alcani parece aceptar cargos para luego contradecirse o desdecirse permanentemente, apoyándose a veces en sutiles imprecisiones lingüísticas, detalles triviales o vacíos semánticos de los testimonios. También podemos ver que, a pesar de las numerosas acusaciones, juicios y hostigamiento por parte de españoles, los caciques no 
parecen haber sufrido condenas graves. Pascual Alcani fue condenado y esta pena se pudo concretar sólo luego de un largo proceso donde el propio regidor parecía ser objeto de burla y que incluyó el desplazamiento del propio regidor a Mogna y numerosas dilaciones. La condena fue muy limitada para el esfuerzo invertido por las autoridades, alcanzando solo unos meses de cárcel y el territorio del cacique continuó siendo relativamente autónomo como insinuaba un informe de 1806 del diputado del Real Consulado en la Ciudad de San Juan, José Godoy Oro. Mogna, decía, "se halla poseída de cuatro o cinco indios impuros malévolos, que debiendo haberlos despedido, y puesto dichos terrenos en manos de industriales, como corresponde, vemos con dolor reinar allí la pereza y la inacción" (Tjarks, 1958: 233).

Finalizando este artículo creo que es posible reconocer en la historia de los caciques Alcani prácticas, estilos, y estrategias de lucha que constituirán un repertorio activo en las demandas, defensas y acciones de indígenas en Cuyo los laguneros de Guanacache y otros actores rurales subalternos a lo largo del siglo XIX.

El primero de ellos son las tradiciones de uso del sistema judicial para defender sus intereses y obtener reconocimiento, alternando esta estrategia con el ejercicio de la violencia de mediana intensidad, mediante el cuatrerismo, exacciones y redistribución, hasta la desobediencia y sabotaje a la autoridad estatal en el territorio. La impronta de la tradición judicial y política indígena es patente cuando comparamos los juicios a caciques y negociaciones del siglo XVIII con las protagonizadas por las autoridades locales laguneras del XIX. Estas están sostenidas sobre similares figuras del derecho indiano, apoyadas en jurisprudencia colonial como el status reduccional y en reconocimientos políticos coloniales como la compensación de servicios armados por tierras. También aparecen como un legado perdurable la táctica judicial, la retórica y las formas de testimonio de los líderes indígenas a cargo de las demandas o defensas. Por un lado, la auto-minusvalorización, las apelaciones de protección y a la legitimidad de los derechos de los grupos marginados. Por el otro la dilación, la elusividad de los argumentos y la contradicción paralizante en los juicios cuando las condiciones no son favorables. Y finalmente cierto cinismo y picardía en confrontar la autoridad, evidenciar tensiones y proponer acuerdos políticos apelando a la necesidad de gobierno y la dificultad de los líderes de controlar a sus peligrosos representados.

Segundo, la construcción política del reconocimiento oficial u oficioso del liderazgo por parte del estado o las elites criollas, sobre la base de la escasa gobernabilidad de las poblaciones rurales. Esto último, notablemente, podemos observarlo en el discurso de los líderes militares laguneros como Santos Guayama y otros caudillos criollos de mayor envergadura como el "Chacho" Peñaloza, quienes se adjudican el rol de mediadores apoyados en la representación local y en las mutuas debilidades de los gobiernos y de los líderes para controlar la población. Tal parece que el cacique ocupa el mismo lugar que describía Sarmiento para las autoridades civiles y militares rurales del siglo XIX, como el juez de paz y el comandante de campaña: "Como la ciudad es débil en el campo, sin influencia y sin adictos, el gobierno echa mano de los hombres que más temor le inspiran, para encomendarles este empleo a fin de tenerlos en su obediencia; manera muy conocida de proceder de todos los gobierno débiles" (Sarmiento, 1963: 98).

Tercero, el sostenimiento de la ocupación y la resistencia territorial mediante acciones directas (que en el siglo XIX alcanzará al bandolerismo y el estado insurreccional en diversas ocasiones) combinadas con la evasión del control estatal efectivo y la acción de la justicia colonial cuando ésta se proyecta sobre tales prácticas.

Finalmente, la apelación a - y el conocimiento de- las memorias de lucha de sus ancestros. Vemos que Pascual Alcani testimonia a principios del siglo XIX sobre la historia del grupo desde su traslado a distintos parajes en el siglo XVII, los conflictos con sus encomenderos y los reconocimientos legales coloniales sobre cacicatos y tierras por parte de la Real Audiencia. También, reconstruye una genealogía que lo sitúa en un linaje de caciques que abarca desde 1630, cuando habría nacido Diego Alcani hasta (si seguimos a Sarmiento) 1830, con la muerte de Pascual. Como sugiere su testimonio, y las prácticas de los caciques señaladas en diversos juicios, estos probablemente transmitían una memoria social y territorial que de hecho se habría dado entre muy pocas generaciones. El período de vida de Diego, Santiago, Francisco y Pascual Alcani abarca dos siglos en solo cuatro generaciones, culminando precisamente cuando comienza un ciclo de demandas indígenas, autonomía y resistencia territorial en las Lagunas de Guanacache, lideradas por autoridades civiles, primeros los "jueces laguneros" y luego subdelegados departamentales y comisarios (Escolar, 2013, 2015). Podemos preguntarnos lícitamente, entonces, si esas memorias políticas, identidades y sentidos territoriales indígenas de la saga de los antiguos caciques no pueden haber perdurado en el siglo XIX, influyendo en las acciones e identidades subalternas, discutiendo el proceso independentista y de formación de la nación como una tábula rasa etnopolítica.

Mendoza, 23 de febrero de 2020

\section{Agradecimientos}

Expreso mi gratitud especial al personal de los archivos relevados, en particular el de los Tribunales de la Provincia de San Juan por su inestimable colaboración en la búsqueda de fuentes. También deseo agradecer el detallado dictamen de los/as evaluadore/as anónimos designados, 
los cuales me permitieron mejorar sustancialmente el manuscrito e identificar nuevos problemas.

\section{Repositorios}

\section{Archivo Histórico de Mendoza}

Archivo Histórico de San Juan

Archivo Nacional de Chile

Archivo de los Tribunales de la Provincia de San Juan

Instituto Nacional de Antropología y Pensamiento Latinoamericano

\section{Bibliografía}

Adamosky, E. (2019). El gaucho indómito: De Martín Fierro a Perón, el emblema imposible de una nación desgarrada. Buenos Aires Siglo XXI, P. 173-189.

Ardissone, R. y Grondona, M. F. (1957). La instalación aborigen en Valle Fértil (Buenos Aires: Instituto de Geografía, FFyL, Universidad Nacional de Buenos Aires.

Boixadós, C. (1999). “Expropiación de tierras comunales indígenas en la provincia de Córdoba a fines del siglo XIX. El caso del pueblo de La Toma". Cuadernos de Historia, 2, 87-113.

Boixadós, R. (2007-2008). "Recreando un mundo perdido. Los pueblos de indios del valle de Famatina en la visita de 1667 (La Rioja, gobernación de Tucumán)". Población y Sociedad 14-15, 3-31.

Boixadós, R. (2008). "Caciques y mandones de Malligasta. Autoridad y memoria en un pueblo de indio de la Rioja Colonial". Andes, 19, 251-278.

Cabrera, P. (1929). "Los aborígenes del país de Cuyo". Revista de La Universidad Nacional de Córdoba, XV (7-8), 3-53.

Canals Frau, S. (1946). "Etnología de los huarpes. Una síntesis". Anales del Instituto de Etología Americana, 7, 9-149.

Canals Frau, S. (1956). "El pueblo de Capayán y los indios capayanes". RUNA, Archivo Para Las Ciencias Del Hombre, 7 (1), 29-37.

Casas, J. (2009). Mogna, larga distancia, el pueblo de la travesía. San Juan, Universidad Nacional de San Juan, Facultad de Ciencias Sociales.

Chumbita, Hugo y Robledo, Victor H. (2011). La causa perdida del Comandante Severo Chumbita. Rebelión de las montoneras federales 1862-1868. Editorial Ross, Rosario
Contreras Cruces, H. (1998). "Los caciques de Talagante durante el siglo XVIII. Legitimidad, prestigio y poder, 1718-1719". Cuadernos de Historia 18, 139-167.

Contreras Cruces, H. y Godoy Orellana, M. (2019). Chile en siglo XIX ¿Una república sin indios? (2019). En Escolar, D. y Rodríguez, L.B. (Eds.). Más allá de la extinción: Identidades indígenas en la Argentina criolla, siglos XVIII-XX (pp. 237-252). Buenos Aires: SB.

Escolar (2007). Los Dones étnicos de la Nación. Identidades huarpes y modos de producción de soberanía en Argentina. Buenos Aires, Prometeo.

Escolar (2013). "Huarpes Archives in the Argentine Desert: Indigenous Claims and State Construction in NineteenthCentury Mendoza", Hispanic American Historical Review 93 (3), 451-483.

Escolar (2015). "Jueces indígenas, caciques criollos: autonomía y estatalidad en Guanacache, Mendoza (siglo xix)", Tiempo Histórico, 9, 37-72.

Fandos, C., Teruel, Ana. (2009). "Procesos de privatización y desarticulación de tierras indígenas en el norte de Argentina en el siglo XIX". Revista Complutense de Historia de América, 35, 233-255.

Farberman, J. (2004). "Curacas, mandones, alcaldes y curas. Legitimidad, autoridad y cohersión en los pueblos de indios del Santiago del Estero, siglos XVII y XVIII". CLAHR 13 (3), 367-397.

Farberman, J. (2009). Las márgenes de los pueblos de indios. Agregados, arrendatarios y soldados en el Tucumán colonial. Siglos XVIII y XIX, Nuevo Mundo Mundos Nuevos. http:// nuevomundo.revues.org/57474 .

Gargiulo, H. y Casas, J. (Eds.) (2006). Buenaventura Luna y la cultura popular. San Juan, UNSJ.

Garzón, Ignacio. "Fragmento de la memoria del Marqués de Sobremonte, Gobernador Intendente de Córdoba, escrita para su sucesor el Coronel de Ingenieros D. José González (año 1796)". Crónica de Córdoba (Aveta, Córdoba), 1898, 1, 385-390. En Revista de la Junta de Estudios Históricos de Mendoza, 1968, 469-471.

Godoy Orellana, M., y Contreras Cruces, H. (2008). Tradición y modernidad en una comunidad indígena del Norte Chico: Valle Hermoso, siglos XVII al XX. Editorial Universidad Bolivariana.

Isla, A. (2002). Los usos políticos de la identidad. Indigenismo y Estado, Buenos Aires, Editorial de las Ciencias.

Jara, A. (1958). “Importación de trabajadores indígenas 
en el siglo XVII." Revista Chilena de Historia y Geografía $124,175-212$.

León Solís, L. (2011)." 'Los indios en el día aumentan su desvergüenza...' Rebeldía, disputas y conflictos en el 'pueblo de indios' de Pomaire (Chile Central), 1790-1811". Cuadernos de Historia, 35, 93-134.

López, C. (2006). Tierras comunales, tierras fiscales: El tránsito del orden colonial a la revolución. Anuario del CEIC, 3 (La propiedad de la tierra: pasado y presente), 39-67.

López de Albornoz, C. y Bascary, A. M. (1998). Pueblos indios de Colalao y Tolombón: identidad colectiva y articulación étnica y social (siglos XVII-XIX), Humanitas, 27: 71-112.

Méndez, L. M., Ana T. Fanchin. (1998). Demografía, comercio y tráfico entre Cuyo y Chile, 1778-1823. Revista de Estudios Trasandinos 3, 113-138.

Michieli, C. T. (2000). La disolución de la categoría jurídico-social de «indio» en el siglo XVIII: El caso de San Juan (Región de Cuyo). Universidad Nacional de San Juan, Facultad de Filosofía Humanidades y Artes, Instituto de Investigaciones Arqueológicas y Museo.

Michieli, C. T. (2004). La Fundación de Villas en San Juan (siglo XVIII). Buenos Aires: Sociedad Argentina de Antropología.

Molina Otárola, R. y Campos Muñoz, L. (2017). "Confín geográfico, refugio indígena, pueblo de indios y etnogénesis en el Huasco Alto, (Chile)". Revista de Geografía Norte Grande, 68, 123-140.

Morales Guiñazú, F. (1938). Primitivos habitantes de Mendoza. Mendoza: Best Hermanos.

O'Phelan Godoy, Scarlett. (1997). Kurakas sin sucesiones. Del cacique al alcalde de indios. Perú y Bolivia, 17501835. Cusco: Centro Bartolomé de Las Casas.

Prieto. M. de R. (2000). "Formación y consolidación de una sociedad de frontera en un área marginal del Reino de Chile: La provincia de Cuyo en el siglo XVII". Anales de Arqueología y Etnología 52-53, 17-366.

Prieto, M. del R. (1976). “El proceso de aculturación de los huarpes de Mendoza". Anales de Arqueología y Etnología XXIX-XXXI, Universidad Nacional de Cuyo, Facultad de Filosofía y Letras: 237-72.
Rodríguez, L. (2011). El viaje de Don Lorenzo y otros "peregrinajes". Reclamos territoriales, identidad y memoria en la comunidad de Amaicha del Valle. En L. Rodríguez (comp.), Resistencias, conflictos y negociaciones. El valle Calchaquí desde el período prehispánico hasta la actualidad (123-144). Rosario: Prohistoria.

Rodríguez, L. (2017). “Cuyo nombramiento no lo obtuvo sino por su buena conducta pues nunca fue indio de aquel pueblo". Caciques y Alcaldes en el pueblo de Colalao y Tolombón entre la colonia y la república". Tzintzun. Revista de Estudios Históricos 66 (julio - diciembre 2017), 11-36.

Sarmiento, D. F. (1966 [1850]). Recuerdos de Provincia. Buenos Aires: Ed. Sopena Argentina.

Sarmiento, D. F. (1963 [1845]). Facundo. Buenos Aires: Ed. Losada.

Sarmiento, D. F. (1947 [1867]): El Chacho. Último Caudillo de la Montonera de los Llanos. En Vidas de Fray Félix Aldao y El Chacho (pp. 69-236). Buenos Aires: Argos.

Serulnikov, Sergio (2004). "Legitimidad política y organización social en las comunidades indígenas de la provincia de Chayanta (siglo XVIII)". Anuario de Estudios Hispano Americanos, LXI (1), 69-101.

Testimonio de un Edicto de D. Francisco Salcedo, Obispo de Santiago de Chile (16-5-1626). 1936., Revista de la Juta de Estudios Históricos de Mendoza, II. Sección Documental.

Tell, S. (2012). Conflictos por tierras en los 'pueblos de indios' de Córdoba. El pueblo de San Marcos entre fines del siglo XVII y principios del siglo XIX. Andes. Antropología e Historia, 23 (1): 71-103.

Tjarks, G. O. E. (1957). “Un informe comercial sanjuanino para la secretaría de Balanza de Madrid." Boletín del instituto de historia Argentina "Dr. E. Ravignani". Año III, $2^{\text {a }}$ serie, $4-6,203-237$ ).

Torre Revelo, J. (1946). El Marqués de Sobremonte, Gobernador intendente de Córdoba y Virrey del Río de la Plata. Ensayo Histórico. Publicaciones del Instituto de Investigaciones Históricas, Facultad de Filosofías y Letras.

Verdaguer, J. A. (1931). Historia eclesiástica de Cuyo (I), Milano: Premiata Scuola Tipográfica Salesiana. 